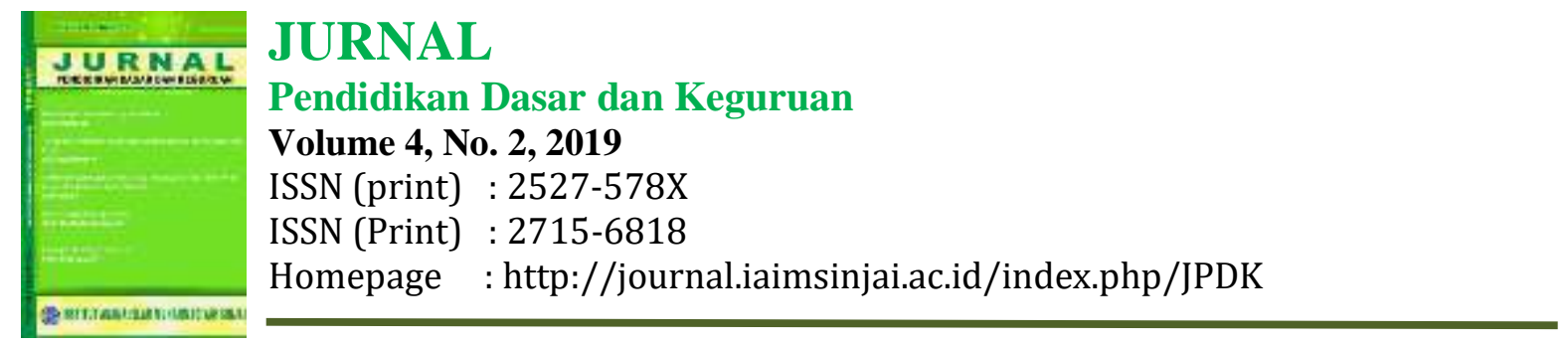

\title{
PENERAPAN STATEGI PEMBELAJARAN AKTIF PREDICTION GUIDE PADA SEKOLAH DASAR
}

\author{
Fitriani $^{1}$, Muhammad Kadir ${ }^{2}$ \\ ${ }^{1}$ Institut Agama Islam Muhammadiyah Sinjai Jl. Sultan Hasamuddin No.20 Sinjai \\ ${ }^{2}$ Institut Agama Islam Muhammadiyah Sinjai Jl. Sultan Hasamuddin No.20 Sinjai \\ Fitridikdas22@gmail.com
}

\begin{abstract}
Abstrak
Penelitian ini bertujuan untuk mengetahui apakah dengan menggunakan strategi pembelajaran prediction guide dalam pembelajaran IPS dapat meningkatkan hasil belajar IPS. Penelitian ini menggunakan pendekatan kualitatif bersifat deskriptif dengan jenis penelitian tindakan kelas yang berdaur ulang/bersiklus yang meliputi perencanaan, pelaksanaan, observasi dan refleksi. Fokus penelitian ini adalah strategi pembelajaran aktif Prediction Guide dengan hasil belajar IPS. Subjek penelitian ini adalah guru dan siswa kelas IV yang jumlahnya 27 siswa terdiri dari 8 laki-laki dan 19 perempuan. Teknik pengumpulan data ini adalah observasi, tes dan dokumentasi. Teknik analisis data kualitatif adalah mereduksi, penyajian data, dan penarikan kesimpulan. Hasil penelitian menunjukkan adanya peningkatan hasil belajar siswa dari siklus I dengan kualifikasi cukup kesiklus kedua dengan kualifikasi baik. Dari hasil tersebut maka dapat disimpulkan bahwa pelajaran IPS tentang koperasi dengan menggunakan strategi pembelajaran aktif prediction guide meningkatkan hasil belajar siswa.
\end{abstract}

Kata Kunci: Startegi Pembelajaran Aktif Prediction Guide, Hasil Belajar Siswa

\begin{abstract}
.
This study aims to determine whether using prediction guide learning strategies in social studies learning can improve social studies learning outcomes. This study uses a descriptive qualitative approach to the type of class action research that is recycled / cycled which includes planning, implementation, observation and reflection. The focus of this research is the Prediction Guide active learning strategy with social studies learning outcomes. The subjects of this study were the teacher and fourth grade students, 27 of whom consisted of 8 male and 19 female students. Data collection techniques are observation, testing and documentation. Qualitative data analysis techniques are reducing, presenting data, and drawing conclusions. The results showed an increase in student learning outcomes from the first cycle with sufficient qualifications in the second cycle with good qualifications. From these results it can be concluded that social studies lessons on cooperatives by using active prediction guide learning strategies improve student learning outcomes.
\end{abstract}

Keyword: Active Learning Strategy Prediction Guide, Student Learning Outcomes 


\section{Pendahuluan}

Pendidikan merupakan usaha yang dilakukan manusia untuk menambah dan memperluas pengetahuannya dalam membentuk nilai, sikap dan prilaku. Pendidikan juga merupakan salah satu kebutuhan manusia yang harus dipenuhi, setiap manusia sampai kapanpun dan dimanapun ia berada tetap membutuhkan pendidikan. Manusia tidak akan berkembang bahkan terbelakang, jika tidak adanya pendidikan. Pentingnya pendidikan sehingga harus diarahkan untuk untuk membentuk manusia yang berkualitas. Mampu bersaing, memiliki budi pekerti luhur dan bermoral yang baik. Untuk membentuk manusia seutuhnya, maka Ilmu Pengetahuan Sosial merupakan salah satu mata pelajaran yang sangat berpengaruh.

Pengertian IPS yang juga dikenal dengan nama Social studies, adalah kajian mengenai manusia dengan segala aspeknya dalam sistem kehidupan bermasyarakat (Rudi, 2011: 16). Hal ini sebagaimana di kemukakan oleh wahab "mata pelajaran IPS di sekolah merupakan mata pelajaran yang mengkaji seperangkat peristiwa, fakta, konsep dan generalisasi yang berkaitan dengan isu sosial. Melalui mata pelajaran IPS, siswa dapat diarahkan untuk dapat menjadi warga Negara Indonesia yang demokratis,, bertanggung jawab, serta warga dunia yang cinta damai. Mata pelajaran IPS dirancang untuk mengembangkan kemampuan anak didik agar menjadi anggota masyarakat yang memiliki pengetahuan, pemahaman, dan kemampuan analisis terhadap kondisi sosial masyarakat dalam memasuki kehidupan bermasyarakat dalam memasuki masyarakat yang dinamis.

Dalam Kurikulum tercantum bahwa "salah satu tujuan pembelajaran IPS SD/MI adalah memiliki komitmen dan kesadaran terhadap nilai-nilai sosial dan kemanusian. Dalam hal ini seorang guru berpean penting dalam dalam penerapan konsep IPS tersebut (Nur, 2009). Menurut Mulyasa "tugas guru yang paling utama terkait dengan mengajar adalah membuat persiapan mengajar yang dijadikan pedoman pembentukan kompetensi siswa”. Dalam melaksanakan psoses pembentukan kompetensi siswa guru dituntut untuk membuat persiapan mengajar yang pada hakekatnya merupakan perencanaan pembelajaran untuk memperkirakan tindakan apa yang akan dilakukan dalam kegiatan pembelajaran ilmu pengetahuan sosial. (IPS).

Tugas guru tidak hanya sekedar menyampaikan informasi, memberikan pengetahuan yang dimiliki kepada siswa sehingga hanya mendorong siswa untuk sekedar menguasai materi pelajaran. Sebab belajar bukanlah sekedar mencatat dan menghafal sejumlah fakta, data, serta konsep atau informasi yang diterima untuk menguasai sejumlah materi pembelajaran melainkan bagaimana seorang guru dapat menfasilitasi siswa agar terjadi suatu proses aktifitas mental dalam berinteraksi dengan lingkungannya dan mengembangkan potensinya sehingga diharapkan prestasi siswa dapat meningkat.

Namun kenyataan, dalam membelajarkan IPS di MI/SD saat ini masih ada sebagian guru yang hanya sekedar mengarahkan agar dapat mengingat dan memahami fakta dan konsep tersebut, strategi pembelajaran tersebut terkesan lebih menekankan pada penugasan sejumlah materi pelajaran, tanpa diselingi dengan tindakan yang bisa membuat siswa lebih rileks dan senang mengikuti pelajaran. Dengan munculnya rasa bosan dalam diri siswa akan mengakibatkan minimnya daya serap siswa terhadap materi yang diajarkan sehingga akan berpengaruh pada hasil belajar siswa.

Berdasarkan hasil observasi awal, hasil belajar siswa terhadap mata pelajaran IPS masih rendah, hal ini ditandai dengan belum adanya siswa yang menghampiri nilai KKM yang telah ditetapkan oleh sekolah. Berdasarkan hasil pengamatan kurang maksimalnya hasil belajar siswa karena dalam proses pembelajaran masih menggunakan metode ceramah, proses pembelajaran masih bersifat testual, atau cenderung hafalan, siswa kurang dilibatkan secara langsung untuk menemukan sendiri konsep materi yang diajarkan. Siswa kurang diberi stimulus untuk mengelola pemikirannya sendiri dalam memahami materi melalui proses pengamatan dan siswa kurang dilibatkan dalam proses kegiatan kerja kelompok. Dari hasil proses belajar seperti di atas membuat siswa mengantuk yang 


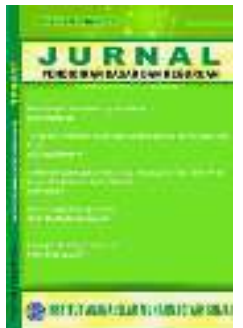

JURNAL

Pendidikan Dasar dan Keguruan

Volume 4, No. 2, 2019

ISSN (print) : 2527-578X

ISSN (Print) : 2715-6818

Homepage : http://journal.iaimsinjai.ac.id/index.php/JPDK

hanya mendengarkan materi pembelajaran, siswa cenderung bermain atau bercerita dengan temannya dan tidak memperhatikan gurunya, siswa enggan menyampaikan pendapatnya sendiri karena kurang di beri stimulus dan siswa kurang paham dengan cara pelaksanaan kerja kelompok karena tidak dibiasakan oleh guru.

Faktor-faktor yang mempengaruhi hasil belajar. Hasil belajar merupakan suatu usaha yang dilakukan oleh siswa sehari-hari ketika belajar. Hasil belajar dapat diketahui melalui kegiatan evaluasi. Evaluasi dilakukan dengan tujuan untuk mendapatkan data pembuktian yang menunjukan sampai dimana keberhasilan siswa dalam pencapaian tujuan pembelajaran. Hasil yang dicapai siswa dipengaruhi oleh dua faktor yakni faktor dari dalam diri siswa dan faktor dari luar siswa. Dari pendapat ini faktor yang dimaksud adalah faktor dalam diri siswa perubahan kemampuan yang dimilikinya seperti yang dikemukakan oleh clark menyatakan bahwa hasil belajar siswa di sekolah 70\% dipengaruhi oleh dan 30\% dipengaruhi oleh lingkungan (Sudjana, 1989). Demikian juga faktor dari luar diri siswa yakni lingkungan yang paling dominan berupa kualitas pembelajaran

Tanpa melihat kemampuan dan perkembangan yang dimiliki siswa, strategi yang digunakan oleh guru tidak layak lagi diterapkan dalam proses belajar mengajar, karena umumnya kejenuhan yang dialami siswa dalam proses pembelajaran disebabkan oleh guru yang terkesan terlalu mendominasi saat pemberian mater, jika siswa hanya mampu mengingat sesuatu dalam jangka pendek, maka siswa dengan mudah melupakannya, selanjutnya jika terus hafalan baru yang mereka tidak tahu asal usulnya akan mengakibatkan hasil belajarnya rendah.

Jika penyebab masalah yang diungkap diatas tidak segera diatasi dan berkelanjutan, maka akan berdampak buruk bagi kemajuan intelektual siswa itu sendiri dan akan berujung pada terpuruknya kualitas belajar sehingga tujuan pendidikan tidak tercapai. Maka dari peningkatan hasil belajar siswa sangat dibutuhkan kemampuan dari guru untuk mengembangkan kreasi mengajar agar mampu menarik minat siswa utnuk belajar. Demikian juga guru tidak hanya mentransfer ilmu yang dimilikinya mellaikan juga mempertimbangkan aspek intelegensi dalam kesiapan belajar siswa, sehingga tidak mengalami semacam depresi mental seperti kebosanan, mengantuk, frustasi terhadap mata pelajaran. Berkaitan dengan hasil belajar siswa rendah, maka hal tersebut tidak boleh dibiarkan berjalan terus. Guru perlu diarahkan untuk menggunakan suatu strategi untuk mengatasi tersebut.

Secara bahasa strategi bisa diartikan sebagai siasat, kiat, trik, atau cara. Sedang secara umum strategi ialah suatu garis besar haluan dalam bertindak untuk mencapai tujuan yang telah di tentukan (Pupuh, 3). Strategi merupakan pola umum yang harus harus dilakukan oleh siswa dalam menciptakan kegiatan belajar mengajar yang lebih interakti, menyenangkan, menantang, memotivasi siswa dalam mencapai tujuan pembelajaran yang telah digariskan (Pupuh, 3). Mansyur mengungkapkan batasan belajar mengajar yang bersifat umum mempunyai empat dasar strategi, yakni;

a. Mengedintifikasi serta menetapkan tingkah laku dan kepribadian anak didik sebagaimana yang diharapkan sesuai tuntutan dan perubahan zaman.

b. Mempertimbangkan dan memilah sistem belajar mengajara yang tepat untuk mencapai sasaran yang akurat.

c. Memilih dan menetapkan prosedur, metode dan teknik belajar mengajar yang dianggap paling tepat dan efektif sehingga dapat dijadikan pegangan guru dalam menunaikan kegiatan mengajar.

Batasan belajar mengajar di atas digunakan dalam menentukan strategi apa yang akan digunakan guru dalam melaksanakan proses belajar mengajar sehinggah terlaksana secara interaktif, menyenangkan, menantang dan memotivasi siswa sehingga tujuan pembelajaran dapat tercapai. Startegi pembelajran aktif Ilmu Pengetahuab Sosial yang dapat digunakan dalam memahami konsep dan prinsip-prinsip Ilmu Pengetahuan Sosial (IPS), di SD/MI adalah dengan menggunakan strategi pembelajarn aktif Prediction Guide. Strategi pembelajaran aktif prediction guide (tebak pelajaran). Strategi ini sangat tepat untuk mendorong siswa agar terlibat dalam proses pembelajaran secara aktif. Dari awal hingga akhir (Ahmad, 2007). 
Strategi pembelajaran aktif adalah strategi yang mengajak siswa untuk belajar secara aktif. Strategi yang aktif dalam pembelajaran menurut Hamzah (2011) siswa diharapkan aktif terlibat dalam kegiatan pembelajaran untuk berfikir, berinteraksi, berbuat untuk mencoba, menemukan konsep baru atau menghasilkan suatu karya. Sebaliknya, anak tidak diharapkan pasif menerima layaknya gelas kosong yang menunggu untuk diisi. Dengan strategi ini siswa dapat menggunakasn kemampuan otak mereka tanpa harus dipaksa. Siswa terlibat sangat aktif saat guru menyampaikan materi pendidikan. Dengan pembelajaran aktif ini, siswa diajak untuk turut serta dalam semua proses pembelajaran tidak hanya mental tetapi juga fisik. Untuk mengaktifkan siswa dalam proses pembelajaran.

Di dalam pengertian strategi Prediction Guide terdiri dari dua kata yaitu Prediction dan Guide. Dalam kamus bahasa inggris-indonesia, Hanif mengartikan "bahwa Prediction berarti ramalan, perkiran atau prediksi. Sedangkan Guide berarti buku pedoman, pandu, memandu,menuntun, atau mempedomani" (Efendi, 216). Jadi, Prediction Guide panduan atau penuntun prediksi. Sehingga bisa dikatakan strategi ini merupakan tebak pelajaran".

Tujuan pembelajar aktif Prediction Guide :Setiap penggunaan strategi pembelajaran dalam proses belajar mengajar tentunya memiliki tujuan yang hendak dicapai. Strategi Prediction Guide merupakan strategi pembelajaran yang tepat digunakan untuk menstimulasi refleksi dan memprediksi materi yang memiliki tujuan dalam penggunaannya dalam pembelajaran. Penggunaan strategi dalam suatu pembelajaran diharapkan dapat meningkatkan hasil belajar siswa.

Dengan strategi ini siswa dituntut untuk aktif dan dapat mempertahankan perhatiannya selama proses pembelajaran berlangsung. Siswa di tuntut untuk dapat mencocokkan prediksi-prediksi mereka dengan materi yang disampaikan oleh guru maupun yang mereka peroleh dari sumber belajar. Langkah-langkah pelaksanaan pembelajaran strategi pembelajaran aktif Production Guide Langkahlangkah strategi pembelajaran aktif prediction Guide, diuraikan oleh Sabri sebagai berikut: 1)Tentukan topik yang akan disampaikan 2). Bagi siswa dalam kelompok-kelompok kecil; 3).guru meminta siswa untuk menebak apa saja yang kira-kira akan mereka dapatkan dalam pertemuan ini; 4).siswa diminta untuk membuat pikiran-pikiran itu dalam kelompok kecil; 5). Sampaikan materi secara interaktif; 6). Selama proses pembelajaran, siswa diminta untuk mengidentifikasi prediksi mereka sesuai dengan materi; 7). Di akhir pertemuan tanyakan berapa prediksi mereka yang mengenal (Ahmad, 2007: 119).

Dari langkah-langkah strategi pembelajaran aktif Prediction Guide ini dapat meningkatkan hasil belajar siswa. Adapun ciri-ciri strategi Prediction Guide. Ciri-ciri strategi Prediction Guide antara lain :1). Guru mengaktifkan siswa dalam belajar 2) guru memberi pertanyaan yang mempunyai beberapa kemungkinan jawaban; 3) guru memberi kesempatan kepada siswa untuk berdiskusi dalam kelompok kecil 4) guru memberi kesempatan kepada siswa untuk menyampaikan jawabannya dan mendemostrasikan sesuai dengan kemampuan mereka; 5) guru dalam ceramah menyampaikan isi poin-poinnya yang sesuai dengan materi dan isi kurikulum; 6) guru memberi kesempatan kepada siswa untuk membandingkan jawabannya dengan poin-poin tersebut.

Strategi ini juga bermanfaat ketika diterapkan karena akan membantu siswa yang kurang memahami pelajaran. Dengan diterapkan strategi pembelajaran aktif tersebut, diharapkan siswa dapat terlibat dalam pembelajaran sejak awal pertemuan hingga akhir dan tetap mempunyai perhatian ketika pengajar menyampaikan materi. Selama penyampaian materi siswa dituntut untuk mencocokkan prediksi-prediksi mereka dengan materi yang disampaikan oleh guru, sehingga proses belajar mengajar yang berlangsung di kelas akan menyenangkan dan siswa tidak akan bosan dan mampu memahami yang akan disampaikan karena dalam strategi pembelajaran aktif tersebut tidak hanya guru yang berperan aktif tapi juga siswa ikut aktif.

Kelebihan Strstegi Pembelajaran Aktif Prediction Guide Zaini (2008: 25) menyatakan bahwa terdapat kelebihan strategi pembelajaran aktif Prediction Guide dapat dilihat sebagai berikut:

a. Siswa dilibatkan (aktif) dalam kegiatan belajar sehingga pengetahuannya benar-benar diserapnya dengan baik.

b. Siswa dapat terlatih mampu prediksi konsep yang mereka alami dalam kehidupan sehari-hari 


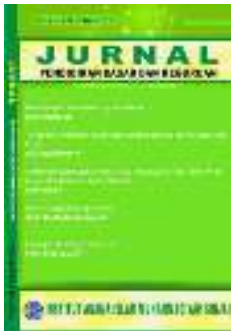

JURNAL

Pendidikan Dasar dan Keguruan

Volume 4, No. 2, 2019

ISSN (print) : 2527-578X

ISSN (Print) : :2715-6818

Homepage : http://journal.iaimsinjai.ac.id/index.php/JPDK

Siswa tertantang untuk berfikir dalam mengingat kembali materi

Dari pemaparan diatas terlihat alasan utama dari pemilihan strategi pembelajaran akatif Prediction Guide terpenuhi, karena tipe ini tidak hanya mengajak anak aktif secara fisik tetapi juga secara mental (Student- Centerd), anak sejak dini telah terlatih mampu memprediksi dan mencocokkan konsep yang telah mereka alami atau pelajari baik di sekolah maupun di rumah pada waktu dulu atau sekarang di samping itu, siswa akan tertantang untuk berfikir dan mengingat- ingat kembali bahan bacaannya selama ini, kemudian kita bisa memotivasi siswa untuk belajar di rumah sebelumnya karena pada pelaksanaan strategi pembelajaran aktif Prediction Guide ini siswa di runtut secara aktif dan bisa mengutarakan prediksi-prediksi mereka sehingga mereka bisa antusias untuk menemukan jawaban masing-masing dari setiap masalah. Dengan demikian dengan adanya Prediction Guide ini anak-anak akan aktif dalam berdiskusi sehingga dapat melihat realita konsep pembelajaran secara nyata sehingga mereka tidak salah konsep.

\section{Metode}

Penelitian ini menggunakan pendekatan kualitatif bersifat deskriptif, karena penelitian ini dinyatakan dalam bentuk verbal dan analisi tanpa menggunakan statistik. Penelitian kualitatif ini berisi garis besar rencana yang mungkin akan dilakukan. Penelitian ini menggunakan pendekatan kualitatif yang mempunyai karakteristik menurut Satori (2009: 27) yaitu : Penelitian kualitatif memiliki latar alamiah dengan sumber data yang langsung dan instrumen kuncinya adalah peneletian; penelitaian kualitatif bersifat deskriptif; penelitian kualitatif bekerja dengan fokus pada proses dan hasil merupakan manusia keniscahayaannya; dan penelitian kualitatif dan cara analisis datanya dilakukan secara induktif. Pendekatan kualitatif berpandangan bahwa realitas dipandang sesuatu yang holistik, kompleks, dinamis, penuh makna dan penuh makna dan pola pikir induktif, sehingga permasalahan yang belum jelas masuh bersifat sementara dan akan berkembang.

Jenis penelitian ini adalah penelitian tindakan kelas yang bertujuan untuk meningkatkan kualitas pembelajaran, bukan menghasilkan pengetahuan (Zainal, 2009: 8). Menurut Aqib langkahlangkah dalam penelitiam tindakan kelas merupakan satu daur yang terdiri dari: a) Tahap perencanaan, b)Tahap pelaksanaan tindakan, c) Tahap pengamatan/observas,d) Tahap refleksi Karakteristik Penilitian Tindakan Kelas menurut Aqib yaitu ;1) An Inquiry of practice from within ( Penelitian berasal dari kerisauan guru akan kinerjanya); 2) Self reflective inquiry ( metode utama adalah refleksi diri, bersifat agak longgar tetapi tetap mengikuti kaidah-kaidah penelitian);3) fokus penelitian berupa kegiatan pembelajaran, dan 4) tujuannya memperbaiki pembelajaran (Djam'an, 2009: 27).

Lokasi penelitian tindakan kelas dilakukan di Sekolah SD Negeri 30 Tongke-Tongke yang berada di jalan kalfataru kecamatan Sinjai Timur Kabupaten Sinjai. Penelitian ini dilakukan di kelas IV yang memiliki keadaan kelas yang cukup baik, dimana kebersiahan kelas terjaga dengan baik dan sarana dan prasarananya pun memadai. Sekolah yang memiliki 12 ruang kelas, 1 ruang kantor, dan 1 ruang kepala sekolah dan 1 perpustakaan.

Dalam memudahkan peneliti dalam memecahkan masalah pada penelitian, maka fokus penelitian ini terdapat 2 variabel yaitu ;

a. Strategi Pembelajaran Aktif Prediction Guide

Strategi pembelajaran aktif tipe prediction guide merupakan strategi pembelajaran yang digunakan untuk melibatkan siswa dalam pembelajaran secara aktif, ulai dari awal sampai akhir pembelajaran. Dalam strategi ini, siswa diminta untuk mengungkapkan pandangan mereka tentang topik pembelajaran semenjak awal kemudian menilai kembali pandangan ini pada akhir pembelajaran.

b. Hasil Belajar Siswa

Hasil belajar siswa adalah perubahan tingkah laku yang dialami oleh individu dalam berinteraksi dengan lingkungannya atau perubahan perilaku yag diperoleh setelah mengalami aktifitas belajar dalam bentuk pengetahuan dan keterampilan. 


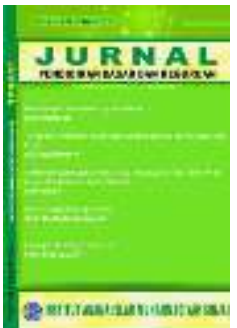

JURNAL

Pendidikan Dasar dan Keguruan

Volume 4, No. 2, 2019

ISSN (print) : 2527-578X

ISSN (Print) : :2715-6818

Homepage : http://journal.iaimsinjai.ac.id/index.php/JPDK

Subjek penelitian ini adalah seluruh siswa kelas IV SD negeri 30 Tongke-Tongke Kecamatan Sinjai Timur Kabupaten Sinjai yang terdaftar dan aktif pada semester genap tahun ajaran 2013/2014 yang berjumlah 27 orang siswa yang terdiri dari 8 siswa laki-laki dan 19 orang siswa perempuan. Penelitian ini mneggunakan rencana penelitian tindakan kelas yaitu recana penelitian berdaur ulang (siklus) yang terdiri dari beberapa langkah-langkah dalam satu daur atau silus yang terdiri dari;

a. Tahap Perencanaan

Dalam melakukan pelaksanaan tindakan kelas, sebelumnya harus melakukan perencanaan atau persiapan dalam pelaksanaannya beberapa perangkat seperti bahan ajar, rencana pembelajaran (RPP) yang diawali dengan;

1) Peneliti bersama guru mata pelajaran IPS menelaah silabus khususnya silabus IPS

2) Peneliti bersama guru menyusun rencana pembelajaran sesuai dengan tahap-tahap strategi pembelajaran aktif prediction guide.

3) Merancang pembuatan lembar kerja siswa untuk memudahkan siswa melakukan penyelidiki atau kerja kelompok.

4) Mendesain alat bantu mengajar dalam rangka membantu siswa dalam memahami materi yang disampikan.

5) Merancang soal-soal tes formatif atau evaluasi.

6) Membuat lembar observasi guru dan siswa, untuk melihat pengaplikasian RPP yang telah disusun, apakah terlaksana dengan baik.

7) Merancang alat penilaian sesuai dengan soal formatif yang telah disusun.

b. Tahap Pelaksanaan

Tahap pelaksanaan tindakan yaitu mengimplementasikan kegiatan yang telah disusun pada tahap perncanaan secara kolaboratif antara wali kelas dan penelitian. Adapun kegiatan yang dilakukan oleh peneliti adalah guru melaksnakan tindakan pembelajaran dalam penyelasian soal-soal dengan menggunakan startegi pembelajaran Prediction Guide Kegiatan pelaksanaan tindakan kelas dilakukan sesuai dengan jenis penelitian tindakan kelas yang dalam kegiatan pelaksanaannya menggunakan beberapa siklus. Setiap siklus terdiri dari beberapa tahapan termasuk dari tahapan pelaksanaan strategi pembelajaran yang digunakan.

c. Tahap Observasi

Tahap Observasi dilakukan selama proses tindakan berlangsu g dengan menggunakan lember observasi yang telah disiapkan yang terdiri dari lembar observasi yang telah disiapkan yang terdiri dari lembar obsrvasi guru dan siswa. Pengamatan dilakukan pada waktu tundakan sedang dilakukan terhadap prilaku dan aktifitas siswa dalam proses pembelajaran berlangsung dan dan dampak yang ditimbulkan dari prilaku guru terhdap siswa selama proses pembelajaran aktif Prediction Guide.

d. Tahap Refleksi

Refleksi dilakukan berdasarkan analisis data, baik observasi maupun data hasil evaluasi. Peneliti menganalis dan merenung hasil tindakan pertama. Refleksi yang akan digunakan sebagai bahan pertimbangan apakah kriteria yang telah ditetapkan tercapai atau belum. Jika tindakan berhasil maka tindakan berakhir atau tidak berlanjut kesiklus berikutnya. Tetapi jika belum berakhir maka peneliti melnjutkan kesiklus berikutnya degan memperbaiki kunerja pembelajaran pada tindakan berikutnya dan seterusnya sampai berhasil sesuai dengan KKM yang telah ditetapkan. 


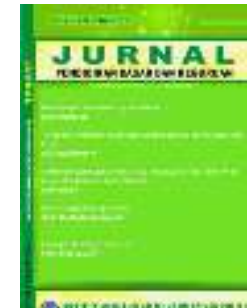

JURNAL

Pendidikan Dasar dan Keguruan

Volume 4, No. 2, 2019

ISSN (print) : 2527-578X

ISSN (Print) : 2715-6818

Homepage : http://journal.iaimsinjai.ac.id/index.php/JPDK

Adapun tahap pelaksanaan penelitian yang dilakukan pada saat pelaksanaan ini adalah tampak pada bagan berikut ini :

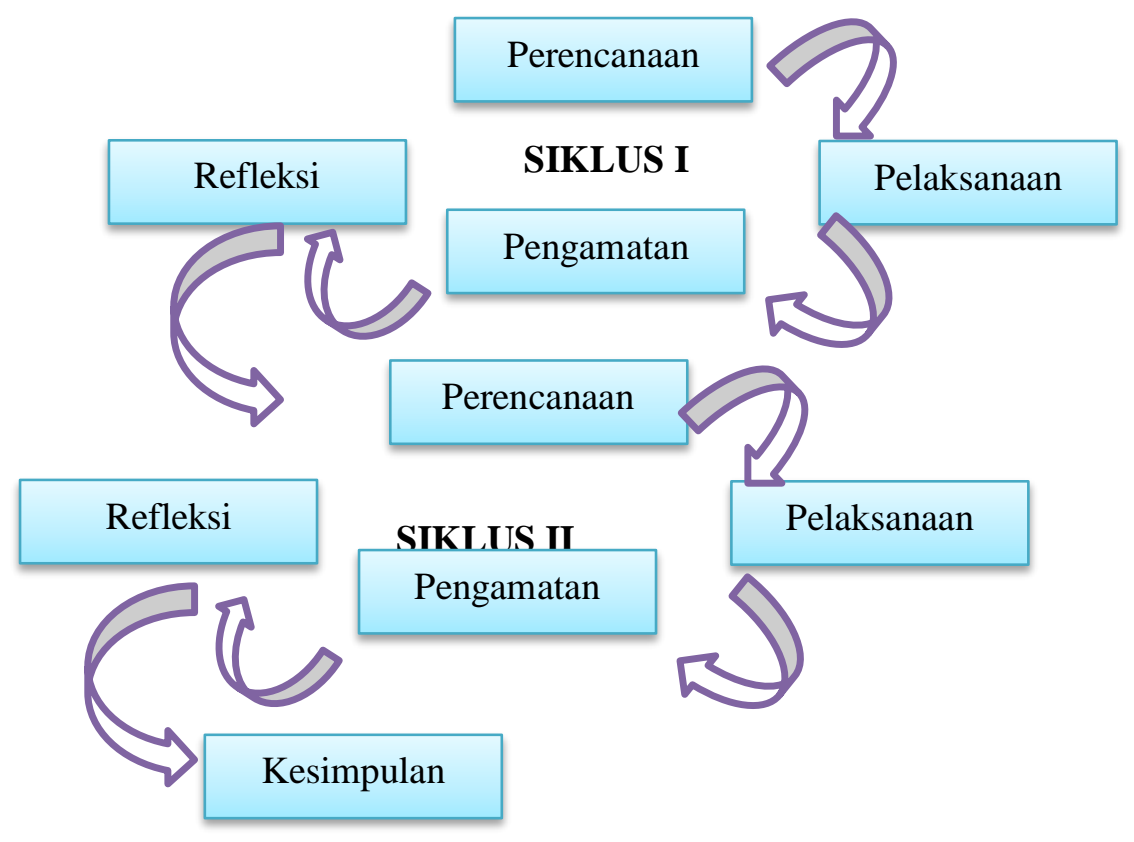

Gambar. 2.1 Siklus Pelaksanaan Penelitian

Teknik pengumpulan data dalam penelitian ini diperoleh dari observervasi/ pengamatan tes dan dokumentasi. Menurut Satori (2009) dengan uraian sebagai berikut;

a. Observasi

Pengamatan dilakukan peneliti di kelas IV SD Negeri 30 Tongkeh-Tongkeh Kecamatan Sinjai Timur Kabupaten Sinjai. Pada pengamatan ini digunakan pedoman pengamatan untuk mencatat hal-hal yang dianggap penting diantaranya; jumlah siswa, nilai yang diperoleh siswa, serta penyebab kurangnya hasil belajar siswa.

b. Tes

Tes dilakukan untuk memperoleh informasi tentang hasil belajr siswa terhadap pelajaran IPS

c. Dokumentasi

Dokumentasi dilakukan untuk melengkapi data yang membuat deskripsi tentang kegiatan pembelajaran yang meliputi aktifitas siswa dan guru serta masalah yang terjadi selama kegiatan pembelajaran berlangsung. Dokumentasi dalam penelitian ini meliputi nilai ulangan, dan foto-foto pelaksanaan tindakan kelas.

Prosedur pengumpulan data pada penelitian ini di,ulai dari pra penelitian yang dilakukan untuk mengetahui masalah apa saja yang dihadapi oleh guru dan siswa dalam proses pembelajaran. Agar data yang diperoleh dari pra penelitian bisa valid, maka perlu menggunakan prosedur pengumpulan data yang baik. Adapun prosedur yang digunakan adalah: 


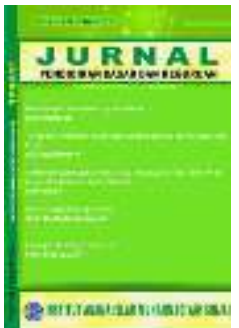

JURNAL

Pendidikan Dasar dan Keguruan

Volume 4, No. 2, 2019

ISSN (print) : 2527-578X

ISSN (Print) : :2715-6818

Homepage : http://journal.iaimsinjai.ac.id/index.php/JPDK

a. Observasi dilkukan dengan mengamati bagaiman proses pembelajaran berlangsung menggunakan strategi pembelajaran aktif Prediction Guide yang berpedoman pada lembar observasi yang ditujukan pada guru dan siswa

b. Tes dilakukan dalam bentuk essay dengan soal-soal yang ebrhubungan materi yang diberikan oleh guru

c. Domuntasi digunakan untuk melihat gambaran pelaksanaan tindakan digunakan baik berupa nilai maupun foto-foto pelaksanaan.

Teknik analis data dalam penelitian ini dilakukan selama dan setelah pengumpulan data. Data yang terkumpul dianalis dengan menggunakan kualitatif. Menurut Arikunto (2010) tahap kegiatan yang dilakukan yaitu: "a) mereduksi data; b) Penyajian data; c) penarikan kesimpulan atau verivikasi. Ketiga kegiatan analisis tersebut akan dijelaskan sebagai berikut :

a. Merediksi data adalah proses kegiatan menyeleksi, mengfokuskan dan menyederhanakan semua data, yang telah diperoleh, mulai dari awal pengumpulan data sampai penyusunan laporan penelitian. Tujuan reduksi data agar data lebih terarah dan lebih mudah dikelola.

b. Penyajian data dilakukan dalam rangka mengorganisasikan reduksi dengan cara menyusun secara naratif sekumpulan informasi yang telah diperoleh dari perencanaan, pelaksanaan, observasi, refleksi dan hasil reduksi, sehingga dapat memberikan kemungkinan kesimpulan dan pengambilan tindakan dan mempermudah dalam membaca data.

c. Penarikan kesimpulan atau verivikasi adalah memberikan kesimpulan terhadap hasil penafsiran dan evaluasi.

Indikator keberhasilan dalam penelitian ini meliputi indikator proses dan hasil dalam menggunakan strategi pembelajaran aktif Prediction Guide. Indikator proses meliputi keatifan siswa dalam proses pembelajaran. Menurut Sutikno (2007: 113) ciri-ciri indikator keberhasilan dalam belajar antara lain :

a. Daya serap terhadap bahan pengajaran yang diajarkan mencapai prestasi tinggi, baik secara individu maupun kelompok;

b. Perilaku yang digariskan dalam tujuan pengajaran khusus telah dicapai oleh siswa baik secara individual maupun kelompok

c. Terjadinya proses pemahaman materi yang secara sekuensial mengantarkan materi tahap berikutnya.

Kriteria yang digunakan untuk mengungkapkan hasil belajar siswa dalam pembelajaran Ilmu Pengetahuan Sosial adalah sesuai dengan kriteria yang diungkapkan oleh Arikunto dan Safruddin $(2004 ; 20)$ pada tabel dibawah ini :

Tabel 1 Kriteria ketuntasan Belajar

\begin{tabular}{cc}
\hline Tingkat Penguasaan & Kualifikasi \\
\hline $81 \%-100 \%$ & Sangat Baik (SB) \\
$61 \%-80 \%$ & Baik (B) \\
\hline $41 \%-60 \%$ & Cukup (C) \\
\hline $21 \%-40 \%$ & Kurang (K) \\
\hline $0 \%-20 \%$ & Sangat Kurang (SK) \\
\hline
\end{tabular}

Dari segi indikator hasil ditandai dengan skor perolehan siswa dari tes yang diberikan dengan kriteria Ketuntasan Minimal yang dirumuskan oleh dewan guru SD Negeri 30 Tongkeh-Tongkeh Kecamatan Sinjai Timur Kabupaten Sinjai. Khususnya pelajaran Ilmu Pengetahuan Sosial yaitu 60 setiap siswa. Maka peneliti menentukan kriteria keberhasilan tinakan pada setiap siklus dikatakan tuntas jika minimal $70 \%$ dari jumlah siswa mencapai nilai minimal $\geq 60$.

\section{Hasil dan Pembahasan}

\subsection{Paparan Data tindakan kelas Siklus I}

Pelaksanaan tindakan pada siklus I dilakukan dalam dua kali pertemuan di kelas IV SD Negeri

30 Tongke-Tongke Kecamatan Sinjai Timur Kabupaten Sinjai. Pertemuan pertama dilakukan pada 
hari selasa tanggal 12 Februari 2013 dan peretamuan kedua dilakukan pada hari selasa tanggal 19 Februari 2013. Kegiatan dilakukan pada tindakan siklus I meliputi beberapa tahap kegiatan yaitu perencanaan, pelaksanaan, observasi dan refleksi. Beberapa tahap kegiatan tersebut dapat diuraikan sebagai berikut :

\section{a. Perencanaan Tindakan Siklus I}

Pada tahap ini rencana tindakan yang telah dibuat aadalah : peneliti bersama dengan wali kelas IV mengadakan pertemuan untuk menlaah silabus khususnya silabus mata pelajaran IPS; setelah menalaah silabus, secara kolaborasi membuat RPP tentang materi pelajaran IPS yang disusun sesuai dengan tahap-tahap strategi pembelajatran aktif Prediction Guide; membuat lembar kegiatan siswa atau atau LKS untuk memudahkan siswa melakukan kerja kelompok; Mendesain alat abntu mengajar yang diperlukan dalam rangka membantu siswa dalam memahami materi pelajaran; membuat soalsoal formatif untuk melihat apakah materi yang diajarkan dikuasia oleh siswa; membuat lembar observasi guru dan siswa, untuk melihat pengaplikasian RPP yang telah disusun, apakah telah terlaksana dengan baik atau tidak.; merancang alat penilaian sesuai denga soal tes formatif yang telah dibuat.

Tindakan siklus I dilaksanakan pada hari selasa tanggal 12 Februari 2013 dan tang 19 Februari 2013 berlangsung selam 105 menit yang dihadiri oleh 27 siswa. Perencanaan pemabelajaran ini mengambil standar kompetensi :

Standar kompetensi

4. Mengenal sumber daya alam, kegiatan ekonomi, dan kemajuan tekhnologi dilingkungan kabupaten kota dan propinsi.

Kompetensi dasar

4.1 Mengenal pentingnya koperasi dalam meningkatkan kesejahteraan masyarakat. Indikator

4.1.1 Menjelaskan pengertian koperasi

4.1.2 Menuliskan lambang-lambang Koperasi

4.1.3 Menjelaskan arti lambang koperasi

Sedangkan untuk indikator untuk pertemuan ke dua adalah :

Indikator :
2.1.1 Mendeskripsikan jenis-jenis koperasi
2.1.2 Menjelaskan manfaat koperasi

\section{b. Pelaksanaan Tindakan Kelas Siklus I}

1) Pertemuan pertama

Pelaksanaan pertemuan I dilaksanakan pada tanggal 12 Februari 2013. Proses pembelajaran koperasi ini dibagi menjadi tiga bagian, yaitu kegiatan awal, kegiatan inti, dan kegiatan akhir. Ketiga kegiatan tersebut akan dijelakan sebagai berikut;

a) Kegiatan awal dimulai dengan persiapan fasilitas yang berkaitan dengan koperasi. Guru mengawali tindakan dengan mengucapkan salam dan mengadakan persiapan pembelajaran yang meliputi mengecek kebersihan kelas, pembacaan doa yang dipimpin oleh salah satu siswa atau ketua kelas sebelum memulai pembelajaran, kemudian mengecek kehadiran siswa dan menyampaikan tujuan pembelajaran serta menyampaikan langkah-langkah pembelajaran yang akan dilakukan.

b) Kegiatan selanjutnya adalah kegiatan inti, kegiatan inti harusnya dilakukan dengan langkah-langkah Prediction Guide sebelum memulai pembelajaran pada kegiatan inti, guru menentukan topik yang akan dibahas namun hal ini tidak terlaksana. Siswa disuruh untuk mempersiapkan segala sesuatu persiapan belajarnya, siswa mempersiapkan segala sesuatu keperluan pembelajaran. Pada pertemuan I guru menentukan topik yang akan dibahas adalah pengertian koperasi, dan manfaat koperasi, setelah menentukan topik pembelajran siswa dibentuk kedalam kelompok-kelompok kecil secara heterogen. Setelah menentukan kelompok, guru meminta siswa untuk menebak apa kira-kira yang akan mereka dapatkan dalam pertemuan ini. 


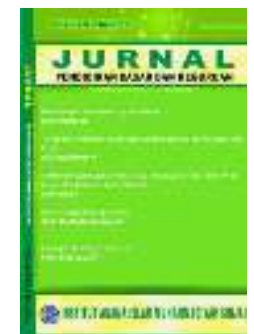

JURNAL

Pendidikan Dasar dan Keguruan

Volume 4, No. 2, 2019

ISSN (print) : 2527-578X

ISSN (Print) : :2715-6818

Homepage : http://journal.iaimsinjai.ac.id/index.php/JPDK

Siswa diminta untuk membuat perkiraan-perkiraan itu di dalam kelompok kecil. Dengan berdiskusi, siswa memperkirakan apa yang akan dibahas. Banyak perkiraan- perkiraan siswa yang mengena, namun adapula yang tidak cocok. Setelah siswa melakukan perkiraan terhadap materi yang akan dibahas, guru membahas atau menyamakan persepsi dengan siswa tentang materi yang akan dibahas. Dari diskusi tersebut ditentukan materi yang akan dibahas yaitu pengertian koperasi, lambang-lambang koperasi. Guru menyajikan materi tersebut secara interaktif. Ketika guru menyajikan materi, siswa menyimak dengan seksama. Setelah penyajian materi, siswa diminta untuk mengidentifikasi prediksi mereka yang sesuai dengan materi. Diakhir pertemuan guru menanyakan kepada siswa tentang beberapa prediksi mereka yang mengena.

c) Kegiatan penutup atau kegatan akhir, guru memberikan kesempatan kepada siswa untuk menyimpulkan materi pelajaran yang telah dipelajarinya. Pada pertemuan ini siswa belum mampu membuat kesimpulan sendiri sehingga siswa dibantu oleh guru. Setelah menyimpulkan materi pelajaran, guru memberikan motivasi kepada siswa agar lebih rajin di rumah, mengulangi pelajaran dan selalu membantu orang tua. Kemudian membaca doa terakhir guru mengucapkan salam penutup untuk mengakhiri pertemua I.

2) Pertemuan kedua

Pelaksanaan pembelajaran pada pertemuan II tanggal 19 Februari 2013, sama dengan proses pelaksanaan pembelajaran I Proses pembelajaran koperasi ini dibagi menjadi tiga bagian, yaitu kegiatan awal, kegiatan inti, dan kegiatan akhir. Ketiga kegiatan tersebut akan dijelakan sebagai berikut;

a) Kegiatan awal dimulai dengan persiapan fasilitas yang berkaitan dengan koperasi. Guru mengawali tindakan dengan mengucapkan salam dan mengadakan persiapan pembelajaran yang meliputi mengecek kebersihan kelas, pembacaan doa yang dipimpin oleh salah satu siswa atau ketua kelas sebelum memulai pembelajaran, kemudian mengecek kehadiran siswa dan menyampaikan tujuan pembelajaran serta menyampaikan langkah-langkah pembelajaran yang akan dilakukan.

b) Kegiatan selanjutnya adalah kegiatan inti, kegiatan inti dilakukan sesuai dengan langkah-langkah Prediction Guide sebelum memulai pembelajaran pada kegiatan inti, guru menentukan topik yang akan dibahas. Sementara guru menentukan topik pembelajaran, siswa mempersiapkan segala sesuatu keperluan pembelajaran. Pada pertemuan II guru menentukan topik yang akan dibahas jenis-jenis koperasi dan manfaat kopearsi setelah menentukan topik pembelajaran siswa dibentuk kedalam kelompok-kelompok kecil secara heterogen. Setelah menentukan kelompok, guru meminta siswa untuk menebak apa kira-kira peran Koperasi dalam kehidupan perekonomian bangsa Indonesia yang akan mereka dapatkan dalam pertemuan ini.

Siswa diminta untuk membuat perkiraan-perkiraan itu di dalam kelompok kecil. Dengan berdiskusi, siswa memperkirakan apa yang akan dibahas. Banyak perkiraan- perkiraan siswa yang mengena, namun adapula yang tidak cocok. Setelah siswa melakukan perkiraan terhadap materi yang akan dibahas, guru membahas atau menyamakan persepsi dengan siswa tentang materi yang akan dibahas. Dari diskusi tersebut ditentukan materi yang akan dibahas yaitu apa saja Peran Koperasi dalam kehidupan perekonomian bangsa Indonesia, dan apa pentingnya Usaha bersama melalui koperasi serta struktur pegawai kopearsi. Guru menyajikan materi tersebut secara interaktif. Ketika guru menyajikan materi, siswa menyimak dengan seksama. Setelah penyajian materi, siswa diminta untuk mengidentifikasi prediksi mereka yang sesuai dengan materi. Diakhir pertemuan guru menanyakan kepada siswa tentang beberapa prediksi mereka yang mengena.

c) Kegiatan penutup atau kegatan akhir, guru memberikan kesempatan kepada siswa untuk menyimpulkan materi pelajaran yang telah dipelajarinya. Pada pertemuan ini siswa belum mampu membuat kesimpulan sendiri sehingga siswa dibantu oleh guru. Setelah menyimpulkan materi pelajaran, guru memberikan motivasi kepada siswa agar lebih rajin di rumah, mengulangi pelajaran dan selalu membantu orang tua. Kemudian membaca doa terakhir guru mengucapkan salam penutup untuk mengakhiri pertemua II. 


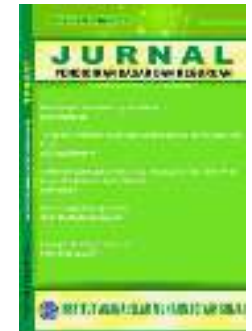

JURNAL

Pendidikan Dasar dan Keguruan

Volume 4, No. 2, 2019

ISSN (print) : 2527-578X

ISSN (Print) : :2715-6818

Homepage : http://journal.iaimsinjai.ac.id/index.php/JPDK

Setelah pelaksananaa pertemuan I dan pertemuan II, peneliti memeriksa hasil pekerjaan siswa. Berdasarkan hasil pekerjaan siswa tersebut, ternyata masih ada siswa belum mampu menyelesaikan semua soal dengan sempurnah. Hal ini terbukti dari nilai rata-rata yang diperoleh siswa mencapai 56,48 dengan ketuntasan klasikal 51, 85. Berdasarkan perolehan nilai tersebut pembelajaran ini dinyatakan belum berhasil sehingga akan diadakan pertemuan siklus II.

\section{c. Hasil Observasi Siklus I}

Observasi dilakukan oleh peneliti di kelas IV SD Negeri 30 Tongke-Tongke Kecmatan sinjai timur kabupaten Sinjai pada pembelajaran siklus I tentang pelaksanaan pembelajaran berlangsung sesuai dengan yang telah disusun namun belum maksimal adapun aspek yang di observasi oleh peneliti yaitu aktifitas guru dan siswa dalam proses pembelajaran dengan strategi Prediction Guide yang pelaksanaannya terdiri dari tujuh tahap pelaksanaan. Sebelum pembelajaran berlangsung guru menyiapkan semua perangkat pembelajaran. Adapun hasil observasi guru yang telah diperoleh pengamat pada siklus I, pertemu I dan II sebagai berikut:

kegiatan awal diawali dengan mengucapkan salam dan mengadakan persiapan pembelajaran dan menyampaikan tujuan pembelajaran serta langkah-langkah pembelajaran yang akan dilakukan. Pada kegiatan awal dilaksanakan dengan baik, karena kegiatan ini sudah biasa dilaksakan oleh guru. Selanjutnya kegiatan inti guru guru tidak menentukan topik yang akan dibahas, guru langsung membahas materi yang akan dipelajari sehingga kategori pelaksanaan pembelajaran strategi prediction guide kurang. Pada pertemuan kedua guru tidak melupakan lagi langkah pertama, guru menentukan terlebih dahulu topik yang akan dibahas. Menentukan topik ini dilaksanakan dengan kategori cukup. Karena kurang menjelaskan topik topik tersebut.

Setelah menentukan topik pembelajaran siswa dibentuk kedalam kelompok-kelompok. Pelaksanaanya terlaksana dengan baik, karena dilakukan di kelompokkan secara heterogen. Setelah itu guru meminta menebak apa-apa saja yang akan mereka dapatkan ddalam pertemuan ini. Pada pertemuan I, guru kategori kurang karena instruksinya jurang jelas dalam proses pelaksanaan pembelajaran. Pertemuan kedua kategori cukup karena sudah meulai memperbaiki cara instruksinya kepada siswa dan mulai mengerti dengan tugasnya.

Selanjutnya perkiraa-perkiraan tersebut dibuat dalam kelompok kecil. Pertemuan pertama kategori kurang karena instruksi yang kurang jelas dan siswa belum paham dengan apa yang akan dilakukan pada saat kerja kelompok. Itu terlihat mereka mengerjakan sendiri-sendiri. Pertemuan kedua kategori cukup diman guru mulai memperbaiki instruksinya dalam membuat perkiraanperkiraan materi apa yang di bahas dalam kelompok.

Setelah topik telah ditentukan pertemuan pertam guru menyajikan materi pembelajaran dengan lengkap namun tidak sistematis, bahasa yang kurang mampu dipahami oleh siswa, sehingga siswa kurang paham dengan materi sehingga kegiatan ini berkategori kurang. Pertemuan kedua guru mulai memperbaiki tata bahasa yang sesuai dengan pemahaman siswa namun belum sistematis sehingga masih kategori cukup.

Setelah menyajikan materi siswa mengidentifikasi prediksi mereka yang sesuai materi. Sama dengan sebelumnya intruksi guru ke siswa kurang dipahami siswa sehingga siswa kurang paham dengan apa yang akan dilakukan sehingga pada pertemuan kedua mulai diperbaiki oleh guru. Diakhir guru menanyakan kepada siswa tentang prediksi mereka yang mengena. Pada pertemuan I kegiatan ini tidak terlaksana karen pengelolaan waktu yang digunakan guru tidak cukup. Pertemuan kedua kegiatan ini terlaksana dengan kategori baik.

Kegiatan akhir guru memberikan bimbingan membuat kesimpulan, memotivasi siswa selanjutnya mengucapkan salam. Pada umumnya kegitan ini terlaksana dengan kategori cukup dengan melihat pelaksanna proses pembelajaran sesuai strategi prediction guide.

Adapun kegiatan siswa diamati kegiatan awal, inti dan penutup yang berlamgsung pada siklus pertama adalah : kegitan awal diawali dengan siswa mengucapkan salam, mengadakan persiapan pembelajaran, menyimak penyampaian tujuan pembelajaran serta menyimak langkah-langkah 


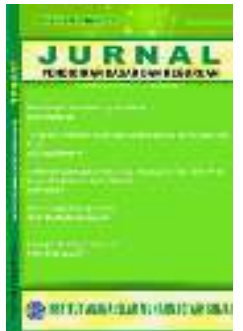

JURNAL

Pendidikan Dasar dan Keguruan

Volume 4, No. 2, 2019

ISSN (print) : 2527-578X

ISSN (Print) : :2715-6818

Homepage : http://journal.iaimsinjai.ac.id/index.php/JPDK

pembelajaran yang akan dilakukan. Kegiatan ini terlaksana dengan baik oleh siswa baik pertemuan I maupun pertemuan II.

Kegiatan selanjutnya kegiatan inti penentuan topik siswa kurang tahu karena guru tidak menyampaikan topik yang akan dipelajari, pertemuan kedua siwa menyimak penyampaian topik oleh guru dengan cukup baik. Kegitan selanjutnya pertemuan pertama pembentukan kelompok siswa melaksanakan dengan baik meskipun kurang paham dengan apa itu kegiatan kelompok pada pertemua I dan pertemuan II, mereka mulai bekerja bersama-sama. Pertemua pertam Pada kegiatan menebak kira-kira apa yang akan dibahas dari topik ini, siswa kurang paham karena instruksi yang kurang jelas pada pertemuan ksedua siswa mulai paham dengan apa yang akan mereka lakukan.

Setelah itu siswa menyimak penyampaian materi yang disajikan guru tanpa memberikan umpan baik pada pertemuan pertama sehingga kategori kurang. Pada pertemuan kedua siswa mulai aktif bertanya dalam penyampaian materi oleh guru. Selanjutnya kegiatan selanjutnya siswa mengidentifikasi prediksi mereka sesuai dengan materi, pada pertemuan pertama kategori kurang karana siswa kurang paham dengan instruksinya. Pada pertemuan kedua siswa mulai mengetahui apa yang harus dilakukan oleh siswa saat mengeditifikasi prediksi mereka dengan materi.terakhir guru menanyakan tentang berapa prediksi mereka yang sesuai dengan topik, pada pertemuan pertama siswa tidak melakasanakan karena waktu, pertemuan kedua siswa melaksanakan kegiatan tersebut dengan menyampaikan prediksi mereka yang benar.

Kegiatan akhir siswa menyimak bimbingan membuat kesimpulan, motivasi guru selanjutnya mengucapkan salam. Pada umumnya kegitan ini terlaksana dengan kategori baik dengan melihat pelaksanna proses pembelajaran sesuai strategi prediction guide.

\section{d. Hasil Refleksi Siklus I}

Berdasarkan hasil tes formatif siklus I ditemukan masih ada beberapa siswa yang belum mampu memahami indikator yang telah disusun. Guru belum sempurnah dalam menerapkan langkahlangkah prediction guide dan siswa pun belum sempurna melaksanakan strategi tersebut.hal ini terbukti dari nilai siswa yang diperoleh siswa rata-rata 56,48 dengan ketuntasan 48,14. Hal ini dikarenakan kurang pahamnya guru dengan strategi tersebut dan penggunaan bahasa yang kurang di pahami oleh siswa. Sehingga solusinya agar guru lebih mengetahui lagi strategi prediction guide dan lebih menata kosa kata yang mudah dipahami oleh siswa. Sehingga siswa bisa melaksakan sesuai langkah-langkah strategi prediction guide.

Berdasarkan analisis di atas, maka dapat disimpulkan bahwa pelajaran materi koperasi dengan pelaksanaan pembelajaran penggunaan strategi prediction guide belum terlaksana dengan sempurnah. Guru perlu melakukan perbaikan dengan merencanakan siklus II. Materi ini akan kembali diajarkan pada siklus II dengan memperhatikan temua-temuan pada siklus pertama, baik pada aktifitas guru maupun siswa. Dengan melaksakan kegiatan pembelajaran sesuai dengan langkah-langkah strategi prediction guide.

\section{Paparan Data Siklus II}

Pelaksanaan tindakan pada siklus II dilakukan dalam dua kali pertemuan di kelas IV SD Negeri 30 Tongke-Tongke Kecamatan Sinjai Timur Kabupaten Sinjai. Pertemuan pertama dilakukan pada hari selasa tanggal 26 Februari 2013 dan peretamuan kedua dilakukan pada hari selasa tanggal 5 Maret 2013. Kegiatan dilakukan pada tindakan siklus II meliputi beberapa tahap kegiatan yaitu perencanaan, pelaksanaan, observasi dan refleksi. Beberapa tahap kegiatan tersebut dapat diuraikan sebagai berikut;

\section{a. Perencanaan Tindakan Siklus I}

Pada tahap ini rencana tindakan yang telah dibuat adalah : peneliti bersama dengan wali kelas IV mengadakan pertemuan untuk menlaah silabus khususnya silabus mata pelajaran IPS; setelah menalaah silabus, secara kolaborasi membuat RPP tentang materi pelajaran IPS yang disusun sesuai dengan tahap-tahap strategi pembelajatran aktif Prediction Guide; membuat lembar kegiatan siswa atau atau LKS untuk memudahkan siswa melakukan kerja kelompok; Mendesain alat abntu mengajar yang diperlukan dalam rangka membantu siswa dalam memahami materi pelajaran; membuat soal- 
soal formatif untuk melihat apakah materi yang diajarkan dikuasia oleh siswa; membuat lembar observasi guru dan siswa, untuk melihat pengaplikasian RPP yang telah disusun, apakah telah terlaksana dengan baik atau tidak.; merancang alat penilaian sesuai denga soal tes formatif yang telah dibuat.

Tindakan siklus I dilaksanakan pada hari selasa tanggal 26 Februari 2013 dan tanggal 5 Maret 2013 berlangsung selam 105 menit yang dihadiri oleh 27 siswa. Perencanaan pemabelajaran ini mengambil standar kompetensi:

Standar kompetensi

2 Mengenal sumber daya alam, kegiatan ekonomi, dan kemajuan tekhnologi dilingkungan kabupaten kota dan propinsi.

Kompetensi dasar

4.2 Mengenal pentingnya koperasi dalam meningkatkan kesejahteraan masyarakat. Indikator

4.2.1 Menuliskan peran koperasi dalam kehidupan perekonomian bangsa Indonesia

4.2.2 Membuat bagan struktur pegawai koperasi

Sedangkan untuk indikator untuk pertemuan ke dua adalah :

Indikator :

2.1.1 Menjeleskan koperasi dan badan usaha lain

2.1.2 Mendeskripsikan perbandingan koperasi dan badan usaha lain

\subsection{Pelaksanaan Tindakan Kelas Siklus II}

1) Pertemuan pertama

Pelaksanaan pembelajaran pada siklus II ini sama dengan pelaksanaan pembeljaran siklus I, Proses pembelajaran koperasi ini dibagi menjadi tiga bagian, yaitu kegiatan awal, kegiatan inti, dan kegiatan akhir. Ketiga kegiatan tersebut akan dijelakan sebagai berikut;

a) Kegiatan awal dimulai dengan persiapan fasilitas yang berkaitan dengan koperasi. Guru mengawali tindakan dengan mengucapkan salam dan mengadakan persiapan pembelajaran yang meliputi mengecek kebersihan kelas, pembacaan doa yang dipimpin oleh salah satu siswa atau ketua kelas sebelum memulai pembelajaran, kemudian mengecek kehadiran siswa dan menyampaikan tujuan pembelajaran serta menyampaikan langkah-langkah pembelajaran yang akan dilakukan.

b) Kegiatan selanjutnya adalah kegiatan inti, kegiatan inti harusnya dilakukan dengan langkah-langkah Prediction Guide sebelum memulai pembelajaran pada kegiatan inti, guru menentukan topik yang akan dibahas. Sementara itu siswa mempersipakan segala keperluan dalam pembelajaran Siswa disuruh untuk mempersiapkan segala sesuatu persiapan belajarnya, siswa mempersiapkan segala sesuatu keperluan pembelajaran. Pada pertemuan II guru menentukan topik yang akan dibahas adalah peran koperasi dalam dalam perekonomian bangsa Indonesia . setelah menentukan topik pembelajran siswa dibentuk kedalam kelompok-kelompok kecil secara heterogen. Setelah menentukan kelompok, guru meminta siswa untuk menebak apa kira-kira yang akan mereka dapatkan dalam pertemuan ini.

Siswa diminta untuk membuat perkiraan-perkiraan itu di dalam kelompok kecil. Dengan berdiskusi, siswa memperkirakan apa yang akan dibahas. Banyak perkiraan- perkiraan siswa yang mengena, namun adapula yang tidak cocok. Setelah siswa melakukan perkiraan terhadap materi yang akan dibahas, guru membahas atau menyamakan persepsi dengan siswa tentang materi yang dibahas. Dari diskusi tersebut ditentukan materi yang dibahas tentang peran koperasi dalam dalam perekonomian bangsa Indonesia. Guru menyajikan materi tersebut secara interaktif. Ketika guru menyajikan materi, siswa menyimak dengan seksama. Setelah penyajian materi, siswa diminta untuk mengidentifikasi prediksi mereka yang sesuai dengan materi. Diakhir pertemuan guru menanyakan kepada siswa tentang beberapa prediksi mereka yang mengena.

c) Kegiatan akhir guru memberikan kesempatan kepada siswa untuk menyimpulkan materi yang telah dipelajari, guru memotivasi siswa selanjutnya berdoa dan mengucapkan salam.

2) Pertemuan Kedua 


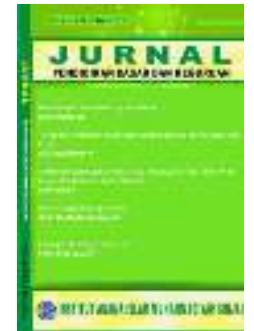

JURNAL

Pendidikan Dasar dan Keguruan

Volume 4, No. 2, 2019

ISSN (print) : 2527-578X

ISSN (Print) : :2715-6818

Homepage : http://journal.iaimsinjai.ac.id/index.php/JPDK

Pelaksanaan pembelajaran pada pertemuan II, sama dengan proses pelaksanaan pembelajaran I Proses pembelajaran koperasi ini dibagi menjadi tiga bagian, yaitu kegiatan awal, kegiatan inti, dan kegiatan akhir. Ketiga kegiatan tersebut akan dijelakan sebagai berikut;

a) Kegiatan Awal dimulai dengan persiapan fasilitas yang berkaitan dengan koperasi. Guru mengawali tindakan dengan mengucapkan salam dan mengadakan persiapan pembelajaran yang meliputi mengecek kebersihan kelas, pembacaan doa yang dipimpin oleh salah satu siswa atau ketua kelas sebelum memulai pembelajaran, kemudian mengecek kehadiran siswa dan menyampaikan tujuan pembelajaran serta menyampaikan langkah-langkah pembelajaran yang akan dilakukan

b) Kegiatan selanjutnya adalah kegiatan inti, kegiatan inti dilakukan sesuai dengan langkahlangkah Prediction Guide sebelum memulai pembelajaran pada kegiatan inti, guru menentukan topik yang akan dibahas. Sementara guru menentukan topik pembelajaran, siswa mempersiapkan segala sesuatu keperluan pembelajaran. Pada pertemuan II guru menentukan topik yang akan dibahas perbandingan koperasi dengan badan usaha yang lain. setelah menentukan topik pembelajaran siswa dibentuk kedalam kelompok-kelompok kecil secara heterogen. Setelah menentukan kelompok, guru meminta siswa untuk menebak apa kira-kira perbedaan Koperasi dan badan usaha yang lain dalam yang akan mereka dapatkan dalam pertemuan ini.

Siswa diminta untuk membuat perkiraan-perkiraan itu di dalam kelompok kecil. Dengan berdiskusi, siswa memperkirakan apa yang akan dibahas. Banyak perkiraan- perkiraan siswa yang mengena, namun adapula yang tidak cocok. Setelah siswa melakukan perkiraan terhadap materi yang akan dibahas, guru membahas atau menyamakan persepsi dengan siswa tentang materi yang akan dibahas. Dari diskusi tersebut ditentukan materi yang akan dibahas yaitu apa saja perbandingan koperasi dengan badan usaha yang lain. Guru menyajikan materi tersebut secara interaktif. Ketika guru menyajikan materi, siswa menyimak dengan seksama. Setelah penyajian materi, siswa diminta untuk mengidentifikasi prediksi mereka yang sesuai dengan materi. Diakhir pertemuan guru menanyakan kepada siswa tentang beberapa prediksi mereka yang mengena.

c). Kegiatan akhir guru memberikan evaluasi masing-masing siswa, selanjutnya bersama siswa membahas masalah-masalah yang titemukan dalam proses pembelajaran. Melakukan pembehasan dan umpan balik atas materi yang diperoleh, siswa menyimpulkan materi kemudian guru memberi motivasi kepada siswa dalam belajar, berdoa kemudian mengucapkan salam.

Setelah pelaksananaa pertemuan I dan pertemuan II pada siklus II peneliti memeriksa hasil pekerjaan siswa. Berdasarkan hasil pekerjaan siswa tersebut, ternyata siswa mampu menyelesaikan semua soal dengan sempurnah. Hal ini terbukti dari nilai rata-rata yang diperoleh siswa mencapai 71,30 dengan ketuntasan klasikal 70,37\% dengan ketuntasan klasikal 51, 85. Berdasarkan perolehan nilai tersebut pembelajaran ini dinyatakan berhasil sehingga siklus berikutnya tidak perlu diadakan lagi.

\section{b. Hasil Observasi Siklus II}

Observasi dilakukan oleh peneliti di kelas IV SD Negeri 30 Tongke-Tongke Kecmatan sinjai timur kabupaten Sinjai pada pembelajaran siklus I tentang pelaksanaan pembelajaran berlangsung. Sesui dengan kegiatan yang telah disusun. adapun aspek yang di observasi oleh peneliti yaitu aktifitas guru dan siswa dalam proses pembelajaran dengan strategi Prediction Guide yang pelaksanaannya terdiri dari tujuh tahap pelaksanaan.

Adapun hasil observasi yang diperoleh oleh pengamat selama kegiatan awal pertemuan I dan II kegiatan awal diawali dengan mengucapkan salam dan mengadakan persiapan pembelajaran dan menyampaikan tujuan pembelajaran serta langkah-langkah pembelajaran yang akan dilakukan. Pada kegiatan awal dilaksanakan dengan baik, karena kegiatan ini sudah biasa dilaksakan oleh guru. Selanjutnya kegiatan inti guru menentukan topik yang akan dibahas,pertemuan I dan II. Setelah itu pembentukan kelompok secara heterogen terlaksana dengan baik.kemudian siswa diharapkan menebak topik materi yang dipelajari. Hasil tebakan mereka didiskusikan secara kelompok kecil hal ini berjalan dengan baik karena diinstrusikan dengan jelas. 


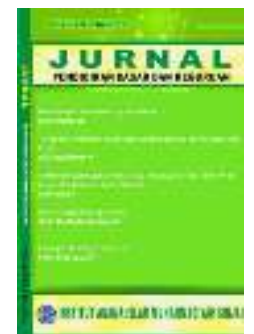

JURNAL

Pendidikan Dasar dan Keguruan

Volume 4, No. 2, 2019

ISSN (print) : 2527-578X

ISSN (Print) : :2715-6818

Homepage : http://journal.iaimsinjai.ac.id/index.php/JPDK

Setelah itu guru menjelaskan materi denga jelas dan menggunakan bahas yang dipahami oleh siswa dan hasil penjelasan tersebut siswa dutuntun untuk mengidentifikasi hasil prediksi mereka yang mengena. Kegiatan tersebut terlaksana dengan baik karena guru jelas dalam instruksinya dan mudah dipahami oleh siswa. Di akhir guru menanyakan berapa hasil prediksi mereka yang benar terlaksana dengan kategori baik.

c) Kegiatan akhir siswa menyimak bimbingan membuat kesimpulan, motivasi guru selanjutnya mengucapkan salam. Pada umumnya kegitan ini terlaksana dengan kategori baik dengan melihat pelaksanna proses pembelajaran sesuai strategi prediction guide.

Adapun hasil kegiatan siswa yang diamati pengamat selam proses pembelajaran terlaksana dengan baik karena apa yang telah diinstruksikan guru pada saat pembelajaran di kelas terlaksana dengan baik.

\section{c. Refleksi Tindakan Siklus II}

Hasil pengamatan pada peoses pembelajaran sudah memahami materi koperasi. Hal tersebut dilihat dari hasil observasi siswa yang menunjukkan ketuntasan siswa yang mempunyai nilai rata-rata 71,30 dengan ketuntasan klasikal 70, $37 \%$.

Ketidaktutasan siswa pada siklus I dalam memahami materi koperasi disebabkan karena masih adanya kelemahan guru dalam menyampaikan materi dan kurangnya pemahaman tentang strategi tersebut dan motivasi siswa dalam belajar pun dalam materi IPS kurang. Namun pada siklus II hal ini tidak terulang lagi karena : guru telah menetukan topik dengan jelas, menyajikan materi dengan jelas, bahasa yang digunakan pun mudah dipahami oleh siswa, penjelasan guru dalam mengintruksikan siswa untuk memprediksi materi pembelajaran pun sudah jelas, guru menyampaikan materi secara interaktif, adanya umpan balik yang dilkukan oleh siswa dan guru maupun guru ke siswa.

Pada bagian ini akan dibahas tentang data yang akan dipaparkan dengan fokus penelitian strategi pembelajaran aktif prediction guide terhadap hasil belajar siswa pada sekolah SD Negeri 30 Tongke-tongke kecamatan sinjai timur kabupaten Sinjai.

Pelaksanaan pembelajaran dengan menggunakan strategi pembelajaran aktif prediction guide dalam penelitian ini diguanakan karena dipandang dapat mengoptimalkan interaksi semua unsur pembelajaran hal ini terlihat dalam upaya guru untuk meningkatkan pemahaman siswa terhadap materi koperasi. Yaitu melibatkan siswa dari awal hingga akhir proses pembelajaran.

Proses pelaksanaan pembelajaran ini diawali dengan menentukan topik untuk mempermudah siswa untuk memahami pelajaran memberikan batasan-batasan materi. Setelah menetukan topik siswa dibagi kedalam kelompok kecil secara heterogen kemudian menebak atau memprediksi apa-apa dlam materi tersebut yang dibuat secara berkelompok, setelah itu guru menjelsakan materi tersebut secara interaktif kemudian siswa menyimak penjelsan siswa untuk mengetahui apakah prediksi mereka cocok ataupun tidak cocok. Sehingga strategi pembelajaran aktif prediction guide ini membuat siswa lebih aktif mulai dari awal sampai akhir.

Pada siklus I strategi pembelajaran aktif prediction guidei ini tidak terlaksana dengan baik sehingga kegiatan siswa pun tidak sempurna mengakibatkan hasil belajar siswapun belum meningkat dilihat dari 27 orang siswa 13 orang siswa yang tidak mampu menjawab soal dengan baik dengan nilai mencapai 58,48 dan ketuntasan belajar 48,15 sedangkan ketidaktuntasan belajar 51,85 sehingga perlu di lakukan upaya kembali dalam siklus II.

Pada siklus II strategi pembelajaran aktif prediction guide terlaksana dengan baik dilihat dari hasil observasi dan hasil belajar siswa dimana pelaksanaan strategi pembelajaran aktif prediction guidekategori baik dan hasil belajar siswa rata-rata 71.30 dengan ketuntasan belajar 70,37, jumlah siswa 27 Orang siswa hanya 8 orang yang tidak mampu menjawab soal dengan benar.

Dari uraian di atas, jelas strategi pembelajaran aktif prediction guide dapat meningkatkan hasil belajar siswa dalam pembelajaran IPS khususnya pada materi Koperasi. Oleh karena itu strategi pembelajaran aktif prediction guide memungkinkan untuk dijadikan sebagai salah satu strategi pembelajaran dalam meningkatkan hasil belajar IPS khususnya di SD/MI. 


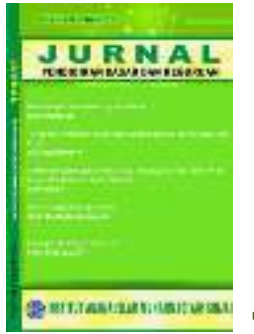

JURNAL

Pendidikan Dasar dan Keguruan

Volume 4, No. 2, 2019

ISSN (print) : 2527-578X

ISSN (Print) : 2715-6818

Homepage : http://journal.iaimsinjai.ac.id/index.php/JPDK

\section{Simpulan}

Berdasarkan pembahasan di atas dapat disimpulkan bahwa guru dalam menggunakan strategi pembelajaran aktif prediction guide pada pembelajaran IPS sangat tepat karena dapat meningkatkan hasil belajar siswa khususnya pada materi koperasi. Terbukti dengan adanya perkembangan aktifitas siswa dan hasil belajar siswa dari siklu I dengan kualifikasi sedang ke siklus II dengan kualifikasi baik.

\section{Daftar Pustaka}

Aqib,Zainal dkk, (2009). Penelitian Tindakan Kelas (PTK) untuk guru D,SLB,TK.Bandung;Yrama Widya.

Arikunto,Suharsimi dan Safruddin. (2004). Penelitian Tindakan Kelas. Jakarta : Bumi Aksara.

Arikunto dan Safruddin, (2010). Evaluasi Pendidikan. Jakarta: Bumi Kasara

Choiriyah,Nur. (2009). Penerapan Strategi Pembelajaran Prediction Guide Pokok materi Klasifikasi Makluk hidup untuk meningkatkan hasil belajar biologi siswa kela VII Smp Negeri Larang Rayung Kabupaten Grobongan Tahun Ajaran 2008/2009. http;//pendidikanku. Wordpress.com/pertanyaan peserta didik (Kamis, 9 januari 2013).

Fathurrohman,Pupuh dan Sutikno Sobry. (2007). Strategi Belajar dan mengajar. Bandung:Refika Aditama

Gunawan,Rudi. (2011). Pendidikan IPS Filosofi, Konsep dan Aplikasi. Bandung: Alfabeta

Hamzah dkk. (2011). Belajar dengan pendekatan PAIKEM. Jakarta: Bumi Aksara.

Hanif F Efendi, Kamus Bahasa Ingris-Indonesia, Indonesia -Inggris. Surabaya:Terbing Terang Surabaya.

Hisyam,Zaini, dkk. (2008). Strategi Pembelajaran Aktif. Yogyakarta: Insan Madani

Sabri,Ahmad. (2007). Strategi Belajar Mengajar Micro Teaching.Padang: Quantum Teaching.

Satori,Djam'an.(2009). Metodologi Penelitian Kualitatif. Bandung.Alfabeta

Sudjana (1989). http://carapedia .com/pengertian defenisi belajar menurut para ahli nfo499.html Senin,7 Januari 2013)

Zaini, Hisyam dkk. (2008). Strategi Pembelajaran Aktif. Yogyakarta. Insan Madani 